\title{
THE FARMER'S PERCEPTION TOWARDS THE INTEGRATED PEST CONTROL BASED ON ECOLOGICAL ENGINEERING IN KARANG SARI VILLAGE OF BELITANG EAST OKU REGENCY, INDONESIA
}

\author{
Arbi M.*, Januarti I., Junaidi N., Yulius, Sari N.S. \\ Study Program of Agribusiness, Faculty of Agriculture, University of Sriwijaya, Indonesia \\ *E-mail: biaarka@gmail.com
}

\begin{abstract}
The purpose of this study was to analyze the perceptions of farmers on the application of integrated pest control based on ecological engineering (refugia) in the village of Karang Sari Subdistrict Belitang III District East OKU, analyze revenues rice farming Obtained rice farmers who implement integrated pest management based on ecological engineering (refugia) in Karang Sari Subdistrict Belitang III East OKU District, Analyzing the relationship between the perception of farmers with paddy farming income that apply integrated pest management based on ecological engineering (refugia). The research was conducted in the village of Karang Sari Subdistrict Belitang East OKU District III. The location determination is done intentionally (purposive). The primaries of data is done on-site research was conducted in October 2018 and finished. The method used in this study is a survey method. Technique intake of sample farmers using census method (total sampling). The results Showed Perception Organic Rice Farmers Against Application of Integrated Pest Management Based Engineering Ecology in Karang Sari Subdistrict Belitang III Kabaputen East OKU currently on the criteria as well as the details of the indicator is the level of knowledge by both criteria, the complexity of the criteria was, the level of compliance with good criteria, the level of ease've seen good results with the criteria, and the rate of profit relative to the criteria. Income of farmers in rice farming activities in the village of Karang Sari Kecamaatan East OKU District III Belitang average of Rp 34.438, 094 / lg / y by using ecological engineering (refugia) in the village of Karang Sari Subdistrict Belitang East OKU District III. Based on the results of the analysis of statistical tests using the Spearman rank correlation coefficient with $n=20$ Obtained by the calculation, the calculated value of $0648>$ table is 0,447 , then the decision to reject $\mathrm{Ho}$ and accept $\mathrm{Ha}$. This means that there is a positive relationship between the perceptions of farmers with paddy farming income of applying ecological engineering (refugia) in the village of Karang Sari Subdistrict Belitang East Oku District III.
\end{abstract}

\section{KEY WORDS}

Perception, integrated pest control, ecological engineering, technology.

Needs of rice in Indonesia have not decreased, but increases from year to year, along with the increase of population is. In order to increase food production of rice, the government is trying to boost paddy production in order to reach self-sufficiency. Many ways are used by the government to increase rice production in the country, mainly to do with the intensification (modern agriculture), among others, with new varieties, fertilizers, and chemical pesticides that can make the problem of pests and diseases is increasing and growing environmental degradation. Integrated Pest Management (IPM) is a way to control plant pests, which is based on a consideration of the ecological and economic efficiency environmentally sustainable agro-ecosystem management (Untung, 2007). Principles of Integrated pest management (IPM) is use for healthy plants, preservation of natural predators, weekly, and farmers as integrated pest control experts. One of the implemation integrated pest management principles preservation of natural enemies by providing habitat and provide food for natural enemies is the usual form of grasses, flowers, and other vegetation on the rice land habitat (Karindah, et.al, 2011).

Various efforts with integrated pest management (IPM), which is more eco friendly have been carried out. According to Baehaki (2016), put forward any strategy other than the 
integrated pest pendalian ecological sustainability, expected socially acceptable and economically beneficial. One of the efforts is controlling intensive ecosystem based on ecological engineering (refugia). Ecological engineering (refugia) is the design of a sustainable system that cares and is consistent with the use of ecological principles that include human activities with the natural environment that benefit both. One of the integrated pest management (IPM) is an ecological engineering (refugia). Due to insect pests and natural enemies of the pest itself instinctively please plants that emit nectar. The smell of nectar will attract insects and the natural enemies of plant pests so that the plants that secrete nectar will gather insect natural enemies and pests that cause insect natural enemies of pests that eat plants. In plants that secrete nectar integrated pest occurs naturally causing environmental balance. The advantages of refugia in microhabitat are able to contribute in conservation of natural enemies, a source of nectar or food for natural enemies of pests before their population in the plant, and the creation of a balanced agro-ecosystem. Rice is main food commodities in Indonesia, cultivated production in almost all islands in Indonesia. South Sumatra Province is one of the many provinces predominantly subsistence farmers of rice. South Sumatra is the third highest rice producing Province of Sumatra Island and was ranked seven in Indonesia. In 2017 paddy rice harvested area increased 0.2 percent (Statistics Agency of South Sumatra Province, 2017).

South Sumatra Province is one of the centers of organic rice in Indonesia, especially East OKU District (OKUT). Regency East OKU (OKUT) is one of the barns in South Sumatra Province who continue to make efforts in order to increase agricultural productivity in order to realize national food power, through the Technology Organic Farming, which is reinforced by signing a Memorandum of Understanding (MoU) about the development of organic rice clusters between East OKU District government with representatives of Bank Indonesia Region VII in Palembang (Yazid et al., 2015). Ogan Ogan Ulu Timur is one of the barns and rice largest in South Sumatra Province who continue to make efforts to increase agricultural productivity into achieve national food security, with the support of technical irrigation channels and the availability of the Weirs Perjaya were able to irrigate most of the rice field that exist in this region.

Subdistrict Belitang III Karang Sari is one area which is located in East Ulu Ogan Ogan applying ecological engineering (refugia) expected from this application can control pests naturally, thereby reducing production costs and maintain environmental balance. Application of ecological engineering has been done in the area of the village of Karang Sari-assisted development of agricultural extension. The implementation of ecological engineering to make changes in the way farmers' farm. Based on the description above, the writer is interested to analyze the perceptions of rice farmers on the application of integrated pest pengedalian based ecological engineering (refugia) in the village of Karang Sari subdistrict Belitang East OKU District III. Based on the problem of analysis, it can be argued some overall objective of this study as follows:

- Analyzing farmer's perception on the application of controls engineering-based integrated pest ecology (refugia) in District III District Belitang East OKU;

- Analyzing income earned rice farming rice farmers who apply controls engineeringbased integrated pest ecology (refugia) in District Belitang East OKU District;

- Analyzing the relationship between the perceptions of farmers with paddy farming income that implement control engineering-based integrated pest ecology (refugia).

\section{METHOD OF RESEARCH}

The research was conducted in the village of Karang Sari subdistrict Belitang East OKU District III. The location determination is done intentionally (purposive) with the consideration that the majority of the population in this district are subsistence rice farmers, where some farmers in the region are using ecological engineering (refugia) to tackle pests and attract natural enemies in rice. Collecting data on the location of the research was conducted in October 2018. 
The sampling method used in this study is census method or total sampling. This method applies when members of a relatively small population. In this study the number of population of farmers of organic rice that implement integrated pest management based on ecological engineering (refugia) in the village of Karang Sari subdistrict Belitang III District East OKU as many as 20 people, the researchers used a total sampling or census by taking all the farmers of organic rice that exist in the sample.

Data collection methods used in this study was farmers directly interviewed using a questionnaire. The data collected in this study consisted of primary data and secondary data. Primary data is data obtained from interviews with farmers rice farmers' perceptions related to the application of integrated pest management based on ecological engineering by using a questionnaire as a list of questions. Secondary data were obtained from the literature, previous research, scientific journals, and related agencies such as the Office of Rural, Agricultural Extension Centers, and the Central Bureau of Statistics of East OKU

Data obtained from the field and processed in accordance with the objectives to be achieved in this study. Data processing is done by using a program on a computer that is the Statistical Program And Service Solution (SPSS) and Microsoft Excel. In answering the first objective of this research is to know the perception of farmers on the application of ecological engineering-based IPM (refugia) using Likert scale. Data measured by five indicators of relative advantage, complexity, conformity level, the level of ease and knowledge. Each question was given a score of 3 on both criteria, a score of 2 for the criteria of being, and a score of 1 for poor criteria.

Table 1 - Interval Perception Class Farmers

\begin{tabular}{llll}
\hline No. & Interval Value Class (total score) & Interval Value Class (per indicator) & Criteria \\
\hline 1 & $\leq x \leq 25.0015 .00$ & $3.00 \leq x \leq 5.00)$ & Bad \\
2 & $25.00<x \leq 35.00$ & $5.00<x \leq 7.00)$ & Moderate \\
3 & $35.00<x \leq 45.00$ & $7.00<x \leq 9.00)$ & Well \\
\hline
\end{tabular}

To answer the third objective, analyzing the relationship perception rice farmers with farm income Spearman rank correlation analysis was used. Spearman Rank correlation formula is as follows:

$$
r_{s}=1-\frac{6 \sum \mathrm{d}^{2}}{\mathrm{n}\left(\mathrm{n}^{2}-1\right)}
$$

Spearman Rank correlation can be calculated using SPSS with the rules of the following decisions:

$$
\begin{gathered}
\text { rs hit } \geq r_{s} \alpha(n)=\text { Reject Ho } \\
\text { rs hit } \leq r_{s}(\alpha / 2)(n)=\text { Thank Ho }
\end{gathered}
$$

To facilitate interpretation of the strength of the relationship between two variables, the relationship diinterprestasi using rules Guilford (Guilford Empirical Rule) as follows:

- 0 - <0.2: Correlation slightly; the relationship is almost negligible.

- $\geq 0.2-<0.4$ : Small correlation; low relationships.

- $\quad \geq 0.4$ - <0.7: Correlation moderate; substantive relationship.

- $\quad \geq 0.7-<0.9$ : High correlation; strong relationships.

- $0.9-<1.0$ : Correlation of the very high: very strong relationship.

\section{RESULTS AND DISCUSSION}

Perception of farmers on Integrated Pest Management (IPM) Based Rekaysa Ecology (refugia) in the village of Karang Sari subdistrict Belitang III District East OKU measured by 
five indicators, they are the level of knowledge, level of complexity, the degree of conformity, the ease seen the results, and the level of relative advantage.

The level of knowledge is the information known to the farmers on integrated pest management based on ecological engineering (refugia). Perception of farmers on the application of integrated pest ecological engineering as a degree of knowledge assessed whether know about refugia cultivation of rice paddy fields, whether the source of information about the cultivation of refugia available, whether interacting or communicating with other farmers who apply refugia. perception of farmers on the knowledge level indicators included in both criteria with a score of 7,15 means that the level of knowledge of good farmers and optimal for the farmers in the village of Karang Sari in cultivating refugia.

Indicators measuring component on whether to know about the cultivation of rice paddy fields refugia has a score of 2,85 with both criteria. This shows that the farmers already know how cultivation refugia. Farmers consider that the presence of crops are grown refugia to attract natural enemies and pests do not directly attack the rice plant. So that pests and natural enemies that attack rice crops in the village of Karang Sari looks slightly and that farmers can conserve the use of pesticides. Measurement indicator of whether the source of information on cultivation available refugia has a score of 2,70 with good criteria means that the information obtained directly from the farmer helped farmer groups and agricultural extension agencies but it is also the application of ecological engineering (refugia) This includes a program of the government in dealing with pests and attract natural enemies that attack rice plants. Measurement indicator of whether the interaction or communication with farmers in other villages to apply refugia has a score of 1,60 with a bad criteria. This means farmers are not good communication because there are farmers who are still skeptical about the implementation of integrated pest management berbbasis ecological engineering (refugia). If farmers can communicate well, then the farmer can each get the experience that can be used in science and new insight.

The level of complexity is the level of innovation that are considered difficult to understand and use. Perception of farmers on integrated pest management based on ecological engineering complexity level measured by indicators refugia application more easily than a conventional way, the application does not require any special skills refugia in the application, the application of refugia is more practical than the conventional way.

Farmer's perception of the complexity level indicators included in the criteria of being with a score of 6,60 means that the level of complexity in the village of Karang Sari is not too complicated in its application. Indicators measuring components of the application of refugia more easily compared with the conventional way has a score of 2,20 with the criteria being. This is because farmers still have to cultivate plants that grow well refugia that can attract natural enemies or pests that attack rice plants. Indicators measuring components of the application does not require any special skills refugia has application to a score of 2,25 with the criteria being that means the application of refugia is not too complicated to reduce natural enemies and pests, so it does not need special skills such as the manufacture of pesticides and spraying. Indicators measuring components of the application of refugia is more practical than the conventional way has a score of 2,15 with the criteria being. This is because the application of refugia still have in cultivation but not complicated so that farmers do not need too many pesticides.

Perception of farmers on integrated pest management based on ecological engineering (refugia) measured with rice cultivation with meenerapkan refugia fits better in the neighborhood, the manufacturing cost of IPM refugia less dbandingkan chemical pesticides so as to save the cost of production and IPM refugia is superior from the aspects health and environmental safety, the application in accordance with the required refugia communities or farmers.

Farmer's perception of the level of conformity is included in both criteria with a total score of 7,55 means that the implementation of integrated pest management based on ecological engineering (refugia) in the village of Karang Sari suitable environment where to stay, safe for the environment, and consistent with the needs of farmers paddy. Indicators measuring components of the application of integrated pest management based on 
ecological engineering (refugia) suitable to be applied in the neighborhood had a score of 2,65 with both criteria. Karang Sari including many farmers are applying ecological engineering (refugia). Farmers who apply integrated pest management based on ecological engineering (refugia) applied by organic rice farmers who own paddy field close together so uncontaminated by the use of chemicals in non-organic farming. Therefore, the application of integrated pest management based on ecological engineering (refugia) in the village of Karang Sari suitable to be applied in the neighborhood farmers. Indicators application of ecological engineering of integrated pest management (refugia) for the cost of making IPM refugia cheaper than chemical pesticides so as to save the cost of production and IPM refugia is superior from the aspects of health and environmental safety has a score of 2,50 with good criteria, meaning that the making refugia this is quite easy to be cultivated on the rice field and the environment around the home place to stay before being transferred dilahan rice crop. In addition, seed refugia also help farmers' groups and easily found so that farmers can reduce the cost of buying chemical pesticides. Indicators of implementation of integrated pest management based on ecological engineering (refugia) in accordance with the needs of the community / farmer has a score of 2,40 with both criteria. If viewed in terms of quality, integrated pest management based on ecological engineering (refugia) in accordance with the needs for people requiring food consumption safe and healthy rice. As if it is viewed in terms of quantity, integrated pest management based on ecological engineering (refugia) is currently producing high production, pests and natural enemies that attack rice reduced. Total production produced by farmers in the village of Karang Sari balanced enough for their own consumption and sale.

Based on the results of measuring the perception of farmers on integrated pest management through ease-level indicators seen from the results is the result of these innovations can be seen or felt by farmers. Farmer's perception of the level of visual clarity of the results was assessed by the application of refugia visible rice plants are healthier and growth is better than with conventional methods, by applying refugia evident existing pest in rice plants is reduced, and the production (rice grain) produced in 1 the growing season is higher with the application of refugia.

The perception of farmers on the level indicator visual clarity of the results included in both criteria with a score of 7.65 , which means a healthier plant growth and better than the conventional method, the pests on rice plants is reduced, and production increased. Indicators measuring component of integrated pest management based on ecological engineering (refugia) looks real rice plants are healthier and better growth has a score of 2.55 with both criteria. It can be seen because the farmers do not use chemical pesticides, chemical fertilizers that plants produced more healthy and safe for public consumption. Component indicators refugia evident implement existing pest in rice plant has a score of 2,60 is reduced with good criteria, meaning that it can be viewed as pests found in rice crops reduced and a bit, so do not need to use too much pesticide as well as the resulting production more quality. Indicators of production components produced in one growing season is higher with the application of refugia has a score of 2,50 with good criterion means of production generated is increased. Processing rice plants better attention to fertilizers, pesticides, integrated pest management based on ecological engineering (refugia) that could prevent, reduce pests and natural enemies that attack rice plants so that higher production.

Based on the results of measuring the perception of farmers on integrated pest management through indicators of relative advantage means a level of innovation that can be received by the farmer and is deemed better than previous technology in terms of the economy in order to gain an advantage. Perception of farmers on the gains assessed by saving labor and pesticides, the application of refugia savings time (efficient) to combat pests, applying refugia apparent increase farmers' income.

Farmer's perception of the relative advantage indicators included in the criteria of being with a score of 6.95 means that the relative advantages obtained by farmers give pengehematan fertilizer, labor and pesticides, saving time (efficient) to combat pests, increase farmers' income. Indicators measuring components of refugia provide savings apply fertilizers, pesticides. and labor has a score of 2.40 with both criteria means an organic rice 
farm using compost and liquid organic fertilizer and organic rice farming certainly does not require chemical pesticides. Pests and weeds found in rice crops a little so that labor is also reduced. This is certainly provide benefits to farmers in addition to reducing the cost of production is also getting improved results, safe, healthy for people and farmers.

Applying component indicators refugia savings time (efficient) to eradicate the pest has a score of 2.25 with moderate criteria, meaning that the time required by the same farmers as rice farming that do not implement ecological engineering (refugia). The implementation of integrated pest management based on ecological engineering (refugia) takes during cultivation. Indicators measuring components increased farmers 'income has a moderate score with a score of 2.30 with the criteria being that means farmers' incomes rise. means the reduction of pests on rice plants thus reducing costs so that the revenue generated can be increased. This is certainly provide benefits to farmers so as to increase revenue.

Total score of perception of farmers on integrated pest management based ecological engineering in the village of Karang Sari subdistrict Belitang East OKU District III total score of 35.90 means the overall perception of farmers on integrated pest management based on ecological engineering (refugia) in the criteria well. This proves the opinion or perception of farmers on integrated pest management based on ecological engineering (refugia) enough to bring better changes in rice farming activities. Three indicators of the perception of the level of knowledge, level of conformity, and the level of convenience own criteria. While the level of relative advantage and complexity are still in the moderate category.

Total production cost is the total cost incurred farmers including the amount of total fixed costs comprised of depreciation costs and variable costs total tool in rice farming activities carried out during the rice planting season progresses. The average production cost of Rp 5,643,906 per farmer land size per year. The fixed costs incurred farmer in the village of Karang Sari comprehensive Rp 126431 per claim per year or 2.24 percent and variable costs incurred extensive Rp 5,517,475 per claim per year or a total of 97.76 percent.

Table 2 - The average production

\begin{tabular}{cccc}
\hline No. & Total Production Costs & Cost (IDR / lg / yr) & Percentage (\%) \\
\hline 1 & Fixed cost & 126.431 & 2.24 \\
2 & variable costs & 5.517 .475 & 97.76 \\
\hline & Total & 5.643 .906 & 100.00 \\
\hline
\end{tabular}

Acceptance is the amount of crop production multiplied by the price of rice. Acceptance of this research is the income received by farmers for one year or during the rice planting season were calculated and multiplied from the sales price per kilogram of dried grain harvest (GKP). Results obtained product rice farmers in the village of Karang Sari amounted to 8,350 kilograms per area cultivated with the sale price Rp4.800 per kilogram of dry grain harvest. Furthermore, the resulting grain purchased directly by the groups or places mill, not far from where the rice farming. In Table 3, the average indicated acceptance of rice farmers in the village of Karang Sari.

Table 3 - Average Revenue Rice in the village of Karang Sari

\begin{tabular}{lll}
\hline No. & Commentary & Receipts (IDR / lg / yr) \\
\hline 1 & The selling price (USD / kg) & 4800 \\
2 & Production (kg / GKP) & 8350 \\
3 & Receipts (IDR) & 40.082 million \\
\hline
\end{tabular}

Rice farm income represents the difference between farm receipts with total production costs already incurred during the rice planting season. the income of rice farming is also influenced by the size acceptance and production costs, the greater the acceptance and smaller production cost, the higher the income of farmers, and vice versa the smaller reception and a greater production cost, the lower the income of farmers. Rice farm income in this study said net profit after the proceeds received minus total production costs 
consisting of depreciation costs and variable costs incurred during the production process farmers' rice.

Table 4. The average income of paddy in the village of Karang Sari

\begin{tabular}{llll}
\hline No. & commentary & $\begin{array}{l}\text { Farming income } \\
(\text { IDR } / \mathrm{lg} / \mathrm{yr})\end{array}$ & Percentage (\%) \\
\hline 1 & Reception & 40.082 million & 83.61 \\
2 & Production cost & 5.643 .906 & 16.39 \\
\hline & Income & 3.438 .094 & 100.00 \\
\hline
\end{tabular}

In analyzing the relationship perception of farmers on rice farming income that apply integrated pest pengnedalian based ecological engineering (refugia) using Spearman correlation statistical test. As to analyze the relationship between the farmer's perception assessed based on five indicators, namely the relative advantage, the degree of conformity, complexity, level of visual clarity of the results, and knowledge with rice farming income using Spearman correlation statistical test.

Based on Table 5. research has been done on the relationship between the perception of farmers on rice farming income applying ecological rekaysa (refugia) were analyzed using statistical tests Spearman rank correlation coefficient (r_s) and the correlation coefficient of 0.648. To interpret the relationship between perception and revenue usahatni rice implementing ecological engineering (refugia) in the village of Karang Sari subdistrict Belitang III OKU Regency East that has a correlation was 0.40 to 0.69 . Rule decisions on research with $n=20$ is calculated by comparing the value of $r s$ rs value table. Rs table calculation results obtained from the standard error $(\alpha) 5$ percent or 0.05 and obtained yield was 0,447 . Based on the calculation, the calculated value $0.648>$ table is 0,447 , then the decision to reject $\mathrm{Ho}$ and accept $\mathrm{Ha}$. This means that therea positive relationship between the perception of farmers with paddy farming income applying ecological engineering (refugia) in the village of Karang Sari subdistrict Belitang East Oku District III.

Table 5 - Perception relationship Farmers Against Revenue Farming

\begin{tabular}{l|l|l|r|r}
\hline \multicolumn{2}{c}{ Correlations } \\
\hline \multirow{3}{*}{ Spearman's rho } & Persepsi & Correlation & Persepsi & \multicolumn{1}{c}{ Pendapatan } \\
& & Coefficient & 1.000 & $.648^{* * *}$ \\
Sig. (2-tailed) & .002 \\
Pendapatan & Correlation & 20 & 20 \\
& & Coefficient & $.648^{* * *}$ & 1.000 \\
& Sig. (2-tailed) & .002 & 20 \\
\hline
\end{tabular}

Based on calculations that have been done obtained count of 0.648 , a positive value means that the relationship is in getting anatara variable perception and rice farming income applying ecological engineering (refugia) unidirectional, where increasing perception along with increased revenue. 0.002 significance value $<0.05$, then there is a significant relationship between the perception and the income of farmers applying ecological engineering (refugia) in the village of Karang Sari subdistrict Belitang East OKU District III. Positive correlation value indicates that the direction of a positive relationship, which means that the higher the perception variable refugia farmers on the higher rice farming income variables that apply ecological engineering (refugia) in the village of Karang Sari subdistrict Belitang East OKU District III.

\section{CONCLUSION AND RECOMMENDATIONS}

Based on the results of research in the village of Karang Sari and discussion that has been in jabarkan it can be concluded as follows: 1) Perception of farmers on the application 
of integrated pest management based on ecological engineering (refugia) located on the criteria as well as the details of the indicator is the level of knowledge by both criteria, the complexity of the criteria was, the level of compliance with the criteria, the level of ease seen the results with good criteria, and the rate of profit relative to the criteria of being. So included in both criteria with a score of 35.90. 2) Income of farmers in rice farming activities in the village of Karang Sari Kecamaatan East OKU District III Belitang average of Rp 34,438,094 / $\mathrm{lg} / \mathrm{yr}$ by using ecological engineering (Refugia) in the village of Karang Sari subdistrict Belitang East OKU District III. 3) Based on the results of the analysis using statistical tests Spearman rank correlation coefficient with $n=20$ obtained by the calculation, the calculated value $0.648>$ table is 0,447 , then the decision to reject $\mathrm{Ho}$ and accept $\mathrm{Ha}$. This means that there is a positive relationship between the perception of farmers with paddy farming income applying ecological engineering (refugia) in the village of Karang Sari subdistrict Belitang East Oku District III.

The advice given is based on research that has been carried out as follows: 1) For farmers should be able to have more confidence and apply the knowledge they have been taught well by farmer groups, extension, linked so that the results can increase rice production and rice farming activities to become better and to use the land owned by the maximum extent possible. 2) For the government in this case the Department of Agriculture, Extension Board, Chairman of Farmers Group can improve the quality of the field of agriculture both in terms of knowledge, attitudes, and skills so as to be able to play an active role and help farmers in dealing with the problems in paddy usahataani activities. 3) For further research to assess the sustainability of the implementation of integrated pest management based on ecological engineering (refugia) so that it can be seen how the success of the application of refugia plants and can be seen by comparing the other areas that have not and have successfully implemented.

\section{REFERENCES}

1. Alisa, Ifa. 2007. Perceptions of Farmers against Innovation for Livestock Manure Compost Using P4S Products Bumi Lestari Sragen (Case Farmers in the village of the District Gondang Gondang Sragen). Essay. Socioeconomic ProgramStudi Ranch. Faculty of Animal Husbandry. Bogor Agricultural Institute.

2. Andoko, A. 2008. In Organic Rice Farming. Depok: Sower Self Reliance.

3. The Central Bureau of Statistics. 2017. South Sumatra in Figures 2017. [Online] http://sumsel.bps.go.id. Accessed on August 25, 2018.

4. Baehaki, SE, EH Iswanto, and SW Widodo. 2016. Engineering ecology in the integrated rice crop management perspective. Plant Food Science and Technology 11 (1): 735-64.

5. Basuki, K. 2008. Analysis of Risk Factors Genesis LDB In Mine Operator A Nickel Mining Company in the province. Thesis. Semarang. Master of Health Promotion. UNDIP.

6. Firmanto, BH 2011. Successful Planting Rice In Organic. Bandung: Space

7. Herman, AG Mudjiono, and A. Afandhi. IPM 2014. Based Engineering Ecology against the brown plant hopper rod Nilaparvata lugens Stal (Homoptera: Delphaciae) and Natural Enemies in rice crops. Journal of HPT [online], 2 (2): 79-86.

8. Jauda R, Laoh E, and Timban J. 2016. Farming Income Analysis Tikong Cocoa Village, District Taliabu, Sula Islands. Agri-socioeconomic Volume 12 Number 2. 33-40.

9. Karindah, Purnawingsih, and Astuti. 2011. The interest Anaxipha Longipennis Servile (Orthoptera: Gryllidae) Against Several Types of Rice Field Weeds In the laying. Journal Entomol. Vol 8 No 1, 27-35.

10. Kardinan, A. 2016. Organic Farming Systems. Malang: Intimedia.

11. Kurniawati, N. and E. Martono. 2015. Role of Flowering Plants for Media Conservation of Natural Enemies arthropod. Journal of Plant Protection Indonesia. 19 (2) 53.59.

12. Mayrowani, H. 2012. Development of Organic Agriculture in Indonesia. Agro Economic Research Forum, Volume 30, No. 2 December 2012: 91-108.

13. Purwono, and Purnamawati, H. 2007. Cultivation 8 superior crops. Jakarta: Sower Self Reliance. 
14. Grace, Jalaludin. 2005. Psychology of Communication. Bandung: PT Young Rosdakarya

15. Sarwani. Employees' perceptions 2003. Factors - Environmental Factors Affecting the Company's Employee Motivation Production Department. Essay. Faculty of Animal Husbandry. Bogor Agricultural Institute. Bogor.

16. Soekartawi. 2003. Analysis of farming. Jakarta: Indonesian University.

17. Suitna, RU 2010. Organic Farming Rice Planting Pattern SRI. Bandung: Pustaka Darul Ilmi.

18. Sukirno, 2006. Economic Development. Processes, Issues and policies, Kencana Prenada Media Group

19. Sutanto, R. 2002. Application of Organic Farming, Towards Sustainable Agriculture and Alternative. Yogyakarta: Canisius.

20. Syaipul S, Sa'diyah A, Masduki S. 2018. Effects of Agricultural Extension Performance against Farmers Perception and Application System Organic Rice. Faculty of Agriculture. Tunggadewi Tribhuwana University. Poor. Vol 6 No 1.

21. Fortunately, K. 2006. Introduction of Integrated Pest Management, 2nd Ed. Yogyakarta: Gadja Mada University Press.

22. Main, MZH 2015. At the Rice Cultivation of Marginal Land: Tips for Improving Production. Yogyakarta: CV Andi Offset.

23. Utomo, Priyo. 2012. Perception Raising Farmers against Method against SRI method in Ringgit village Ngombol District of Purworejo. Essay. Purworejo Muhammadiyah University.

24. Wirawan, AE, Djauhari, S. and Sulistyowati, L. 2014. Effects of Difference Analysis Application System and Conventional IPM against Trichoderma Sppada Diversity of Rice. HPT Journal [Online], Volume 2 Number 3, 66-67.

25. Yazid, M, Mulyana E, Purbiyanti, E. 2015. The interest Value Estimation of Land Rice Organic and Non-Organic: Implications Efforts against Pressing Wetland Conservation rate. Research Report. Sriwijaya University. 